\title{
The Potential of HLA-G-Bearing Extracellular Vesicles as a Future Element in HLA-G Immune Biology
}

\author{
Vera Rebmann ${ }^{1 *}$, Lisa Königi, ${ }^{1,2}$, Fabiola da Silva Nardi1 ${ }^{1,3,}$, Bettina Wagner ${ }^{1}$, \\ Luis Felipe Santos Manvailer ${ }^{1,4}$ and Peter A. Horn ${ }^{1}$
}

${ }^{1}$ Institute for Transfusion Medicine, University Hospital Essen, Essen, Germany, ${ }^{2}$ Department of Gynecology and Obstetrics, Essen, Germany, ${ }^{3}$ Laboratory of Immunogenetics and Histocompatibility (LIGH), Federal University of Paraná Genetics Department, Curitiba, Paraná, Brazil, ${ }^{4}$ CAPES Foundation, Ministry of Education of Brazil, Brasilia, Federal District, Brazil

\section{OPEN ACCESS}

Edited by: Joel LeMaoult,

Commissariat a l'Energie Atomique et aux Energies

Alternatives, France

Reviewed by:

Raymond John Steptoe, University of Queensland, Australia Shomyseh Sanjabi,

Gladstone Institutes, USA

*Correspondence:

Vera Rebmann

vera.rebmann@uk-essen.de

Specialty section:

This article was submitted to Immunological Tolerance,

a section of the journal

Frontiers in Immunology

Received: 14 January 2016 Accepted: 19 April 2016

Published: 04 May 2016

Citation:

Rebmann V, König L, Nardi FS, Wagner B, Manvailer LFS and Horn PA (2016) The Potential of

HLA-G-Bearing Extracellular Vesicles as a Future Element in

HLA-G Immune Biology.

Front. Immunol. 7:173. doi: 10.3389/fimmu.2016.00173
The HLA-G molecule is a member of the non-classical HLA class I family. Its surface expression is physiologically restricted to the maternal-fetal interface and to immune privileged adult tissues. Despite the restricted tissue expression, HLA-G is detectable in body fluids as secreted soluble molecules. A unique feature of HLA-G is the structural diversity as surface expressed and as secreted molecules. Secreted HLA-G can be found in various body fluids either as free soluble HLA-G or as part of extracellular vesicles (EVs), which are composed of various antigens/ligands/receptors, bioactive lipids, cytokines, growth factors, and genetic information, such as mRNA and microRNA. Functionally, HLA-G and its secreted forms are considered to play a crucial role in the network of immune-regulatory tolerance mechanisms, preferentially interacting with the cognate inhibitory receptors LILRB1 and LILRB2. The HLA-G mediated tolerance is described in processes of pregnancy, inflammation, and cancer. However, almost all functional and clinical implications of HLA-G in vivo and in vitro have been established based on simple single ligand/receptor interactions at the cell surface, whereas HLA-G-bearing EVs were in minor research focus. Indeed, cytotrophoblast cells, mesenchymal stem cells, and cancer cells were recently described to secrete HLA-G-bearing EVs, displaying immunosuppressive effects and modulating the tumor microenvironment. However, numerous functional and clinical open questions persist. Here, we (i) introduce basic aspects of EVs biology, (ii) summarize the functional knowledge, clinical implications and open questions of HLA-G-bearing EVs, and (iii) discuss HLA-G-bearing EVs as a future element in HLA-G biology.

\section{Keywords: extracellular vesicles, HLA-G, sHLA-G, LILRB1, LILRB2, KIR2DL4, exosome, HLA-G-bearing EV}

\section{INTRODUCTION}

HLA-G is a non-classical HLA class I molecule. It is a potent suppressive molecule that impairs effector functions of immune cells belonging to the innate and adaptive immune system. Under physiological conditions, its surface expression is restricted to the maternal-fetal interface and to immune privileged adult tissues (1). However, secreted soluble forms of HLA-G are detectable in a variety of body fluids such as peripheral blood and amniotic fluids (2), malignant ascites $(3,4)$, 
pleural effusions (5), cerebrospinal fluid $(6,7)$, and sperm (8). Neo-ectopic or aberrant expression of HLA-G has frequently been related to malignancies (9-13), viral infections (14-19) including liver-related hepatitis B (16) and C (18) virus infections, autoimmune disorders (20-22), inflammatory diseases (23), complications $(24,25)$, and transplantation outcomes $(26,27)$.

A unique feature of HLA-G is that it exists in multiple structures, either expressed on the cell surface or in a secreted form. These different forms can mainly be attributed to alternative splicing of the primary transcript and differential association with $\beta 2$-microglobulin ( $\beta 2 \mathrm{~m}$ ). Four isoforms (HLA-G1, G2, G3, and $\mathrm{G} 4$ ) are membrane-expressed and three isoforms express either intron 4 (HLA-G5 and -G6) or intron 2 (HLA-G7) but lack the transmembrane and cytoplasmic domains, resulting in their secretion. With the exception of HLA-G3 (28), all HLA-G structures can create disulfide bounds between two unique cysteine residues at positions 42 (Cys42-Cys42 bonds) and 147 (Cys42-Cys147 bonds) (29, 30). The structures displaying the full-length extracellular domain (HLA-G1 and HLA-G5) are probably the most frequently detected. The structural diversity is further enhanced in that all membrane-expressed structures can also be shed from cell surface by metalloproteases (31) or can be secreted via extracellular vesicles (EVs) (32).

Regarding function, HLA-G and the soluble counterparts preferentially exert their immune modulating or suppressing functions by interaction with the two inhibitory receptors, leukocyte immunoglobulin-like receptor subfamily B member 1 (LILRB1) and LILRB2. LILRB1 is expressed on subpopulations of T-cells, B-cells, and Natural Killer (NK) cells. Monocytes/ macrophages/dendritic cells (DC) express both receptors. These two receptors distinguish between $\beta 2 \mathrm{~m}$-associated and $\beta 2 \mathrm{~m}$-free HLA-G: LILRB1 interacts with HLA-G molecules associated to $\beta 2 \mathrm{~m}$, whereas LILRB2 specifically recognizes $\beta 2 \mathrm{~m}$-free HLA-G $(33,34)$. HLA-G dimers bind to LILRB with a higher affinity and avidity than monomers, resulting in more efficient LILRBmediated signaling $(35,36)$. Additionally, HLA-G has been described to be the sole ligand for the killer immunoglobulin-like receptor 2DL4 (KIR2DL4), exhibiting both an activating and an inhibitory signaling domain. Moreover, soluble forms of HLA-G are able to trigger apoptosis in $\mathrm{CD}^{+} \mathrm{T}$ and NK cells (37) as well as in CD160-bearing endothelial cells (38).

Based on the functionality of receptors and their expression profile, membrane-expressed and soluble forms of HLA-G molecules are involved in immune regulation in pregnancy, inflammation, and cancer. Thus, HLA-G can be considered as an immune checkpoint molecule (39). However, most functional implications of HLA-G in vivo and in vitro have been deduced from the HLA-G1 and HLA-G5 structures and from a rather simple point of view on single ligand/receptor interaction. Interaction of target cells with HLA-G-bearing EVs has typically not been considered. Here, we (i) introduce basic aspects of EVs biology, (ii) summarize the current knowledge and open questions of HLA-G-bearing EVs, and (iii) discuss HLA-G-bearing EVs as a future element in the HLA-G biology.

\section{BASIC ASPECTS OF EV BIOLOGY}

\section{Common Features of Extracellular Vesicles}

Extracellular vesicles are phospholipid bilayer-enclosed vesicles, which are released by most cell types, including immune cells, tumor cells, stroma cells, trophoblast cells, and adult and embryonic stem cells (40). Depending on the cell of origin, state, and micro-environment, EVs are highly heterogeneous in size, membrane composition, and molecular content. According to biogenesis, EVs are specified as exosomes $(70-150 \mathrm{~nm})$, microvesicles $(100-1000 \mathrm{~nm})$, and apoptotic bodies (AB) (>500 nm). Exosomes correspond to intraluminal vesicles (ILVs), formed from inward budding of small-sized plasma membrane and enclosed in multivesicular bodies (MVB). Exosomes are released into extracellular space after fusion of MVB with the plasma membrane (41). In contrast, microvesicles (MV) are formed by outward budding and sission of the plasma membrane. $\mathrm{AB}$ are generated from plasma membrane blebs of cells undergoing apoptosis. Oncosomes, which are generated by the shedding of plasma membrane blebs of non-apoptotic cancer cells (42), and form an atypically large EV population (1,000-10,000 nm). Several proteins are currently used as markers for EVs, including tetraspanins, different heat shock proteins, adhesion molecules, cytoskeletal proteins, and members of endosomal sorting complexes required for transport of exosomes like TSG101 $(43,44)$. However, so far, no specific markers have been identified allowing for the identification of particular EV subpopulations (44).

Different cell types release differently assembled EV. Furthermore, it is tempting to speculate that even individual cells release different EV types. Importantly, the cell of origin controls the molecular composition and cargo (45-48). EVs harbor various types of antigens, cell surface-expressed receptors or ligands including classical and non-classical HLA-G (32, 49-53), bioactive lipids such as prostaglandins (54) and leukotrienes (55). Additionally, EVs can serve as transport cassettes or a disseminated storage pool of bioactive effector molecules, e.g., cytokines transcription factors, growth factors, oncogenic proteins, and genetic information such as mRNA, microRNA (56-59). Here, the lipid membrane of EVs protects their contents against enzyme degradation present in body fluids and thereby facilitate the transfer of their cargo over a short or long distance.

\section{Modes of Interaction between Extracellular Vesicles and Target Cells}

The composition of EVs is responsible for the biodistribution, for the interaction of EVs to target cells or to extracellular matrix. Membrane fusion of EVs to target cells allows the transfer of bioactive molecules, including, e.g., CCR5 (60) and EGFRvIII (61), modifying the recipient cell phenotype. However, the direct fusion of EVs with the plasma membrane of effector cells requires a similar fluidity of the two fusing membranes. This can be achieved in an acidic micro-environment, which naturally occurs inside tumors (62-65) or at neutral $\mathrm{pH}$ in the presence of syncythin (66). 
Besides membrane fusion, EVs can be internalized by different pathways including phagocytosis, clathrin- and caveolinmediated endocytosis, or micropinocytosis (67). With the exception of the latter, the uptake and internalization of EVs are mostly receptor-mediated, e.g., via Hsp90 receptor or scavenger receptor CD36 (66). The expression of adhesion molecules on EVs probably facilitates the specific uptake of EVs, and their internalization by their cognate receptors being expressed on certain tissue or cell populations (68). The internalization of EVs results in the delivery and enrichment of bioactive molecules into the target cell's endosomes. Hence, these molecules may be forwarded to other cell compartments, where they may contribute to an intracellular signaling mechanism.

\section{The Immunological Potential of Extracellular Vesicles}

The communication and immune modulation by EVs take place among cells within same entity or between different types of cells. Various effector cells of the innate and adaptive immune system, including T cells and NK cells, antigen presenting cells (APCs), and mast cells have been reported to donate or to acquire ligand/ receptor/genetic information via EVs. Due to the complex and often antagonistic composition, EVs can mediate gene expression modification, immune activating or immune suppression, introducing homeostasis or immune tolerance by the induction of T cell apoptosis, impairment of DC maturation, or the prevention of NK and T cell cytotoxicity (68-76). Furthermore, the molecular transfer of miRNA by EVs can alter the expression profile of the recipient cell (71). Tumor-derived EVs can stimulate immune suppression and tumor progression in different ways including the inhibition of tumor-specific $\mathrm{T}$ cell function and proliferation (77), the promotion of regulatory T cells subsets (78), and transfer of oncogenic receptors (61).

\section{THE CURRENT STATUS AND OPEN QUESTIONS OF HLA-G-BEARING EXTRACELLULAR VESICLES}

\section{HLA-G-Bearing EVs and Cancer}

Without any doubt, the neo-ectopic expression of HLA-G molecules either on the surface of tumor cells or released as soluble forms can be considered a critical factor for cancer progression. Albeit high blood levels of soluble forms of HLA-G have concordantly been related to cancer, the prognostic relevance of soluble HLA-G in the blood has not always been established as an independent marker in terms of disease progression and survival (39). To date, the source of soluble HLA-G is known. In addition, it is not clarified whether HLA-G-bearing EVs or free soluble HLA-G (sHLA-G $\mathrm{G}_{\text {free }}$ ) are produced by tumor cells and whether both subcomponents contribute to immune evasion of tumor cells.

Secreted HLA-G-expressing EVs (Table 1) have been detected for the first time in supernatants of a melanoma cell line, originated from a HLA-G-positive melanoma lesion (32). Both, the

TABLE 1 | Source of HLA-G-bearing EVs with potential immunological and clinical relevance.

\begin{tabular}{|c|c|c|c|c|c|}
\hline Cell type & EVs source & $\begin{array}{l}\text { Potential target cell } \\
\text { response }\end{array}$ & Function/mechanism & Clinical relevance & Reference \\
\hline & Melanoma & $\begin{array}{l}\text { Tolerance-inducing effect of } \\
\text { melanoma derived } \\
\text { HLA-G-bearing EVs on } \\
\text { immune cells }\end{array}$ & $\begin{array}{l}\text { Potential induction of } \\
\text { inhibitory signaling by } \\
\text { HLA-G1-bearing EVs via } \\
\text { LILRB1/2 receptors }\end{array}$ & Unknown clinical relevance & $(32)$ \\
\hline & Kidney cancer & $\begin{array}{l}\text { Inhibitory effect of } \\
\text { HLA-G-bearing EVs on } \\
\text { monocyte differentiation into } \\
\text { mature DCs and reduced T } \\
\text { cell proliferation }\end{array}$ & $\begin{array}{l}\text { Inhibitory effect of } \\
\text { HLA-G1-bearing EVs on } \\
\text { monocyte differentiation } \\
\text { and their maturation to DCs }\end{array}$ & $\begin{array}{l}\text { Suppression of immune effector } \\
\text { cells by HLA-G1-bearing EVs, } \\
\text { leading to disease progression }\end{array}$ & (83) \\
\hline & Breast cancer & $\begin{array}{l}\text { Modulation of immune effector } \\
\text { functions by circulating } \\
\text { HLA-G-bearing EVs }\end{array}$ & Unknown function & $\begin{array}{l}\text { Association of high circulating } \\
\text { amounts of HLA-G-bearing EVs } \\
\text { to disease progression }\end{array}$ & (84) \\
\hline & Trophoblast & $\begin{array}{l}\text { Modulation of immune effector } \\
\text { functions by cytotrophoblast- } \\
\text { derived HLA-G5-bearing EVs }\end{array}$ & Unknown function & $\begin{array}{l}\text { Unknown clinical relevance, } \\
\text { but potential biomarker for } \\
\text { pregnancy-related disorders }\end{array}$ & (87) \\
\hline & $\begin{array}{l}\text { Mesenchymal } \\
\text { stem/stromal } \\
\text { cells (MSCs) }\end{array}$ & $\begin{array}{l}\text { Induction of tolerance between } \\
\text { graft and host immune cells by } \\
\text { MSCs-derived EVs }\end{array}$ & $\begin{array}{l}\text { Immunomodulation by } \\
\text { synergistic additive effect } \\
\text { of HLA-G, IL-10, and TGF } \beta\end{array}$ & $\begin{array}{l}\text { Potential therapeutic option for } \\
\text { patients with therapy-refractory } \\
\text { GvHD using MSC-derived } \\
\text { HLA-G-bearing EVs }\end{array}$ & (91) \\
\hline
\end{tabular}


cell line cells and the secreted EVs express the full-length isoform HLA-G1. Up to now, it is not known whether HLA-G1-bearing EVs are functionally active to transduce inhibitory signals toward effector cells via the LILRB1/2 receptors, which may spread the tolerogenicity of HLA-G.

The first in vivo existence of HLA-G-bearing EVs was reported for ascites and pleural exudates derived from cancer patients (53). The EV fractions, however, contain ubiquitinated HLA-G molecules with atypically high HLA-G molecular sizes ranging from 50 to $75 \mathrm{kD}$. Generally, ubiquitination is a frequent posttranslational protein modification, by which proteins are targeted to protein degradation or directed to other cellular locations (79, $80)$. Interestingly, EVs contain many polyubiquitinated proteins, which are not integrated into their membrane (81). Thus, the presence of secreted HLA-G5 or HLA-G6 cannot be excluded.

Very recently, we established the prognostic relevance of HLAG-bearing EVs for neoadjuvant chemotherapy-treated (NACT) breast cancer patients for the first time (82). Both, the total amount of HLA-G $\mathrm{G}_{\text {tot }}$ and the amount of sHLA- $\mathrm{G}_{\text {free }}$ were significantly increased in breast cancer patients. Before NACT, sHLA$\mathrm{G}_{\text {free }}$ levels are exclusively related to estrogen receptor expression, whereas high amounts of HLA-G in EVs (sHLA-G $\mathrm{G}_{\mathrm{EV}}$ ) enriched from peripheral blood samples are associated with the existence of circulating stem cell-like tumor cells. Strikingly, despite high amounts of sHLA- $\mathrm{G}_{\mathrm{tot}}$, its prognostic relevance could not be substantiated. However, different impacts on prognosis have been shown for the two subcomponents sHLA- $\mathrm{G}_{\mathrm{EV}}$ and sHLA- $\mathrm{G}_{\text {free }}$ : high sHLA- $\mathrm{G}_{\mathrm{EV}}$ levels are associated with disease progression, whereas high sHLA- $\mathrm{G}_{\text {free }}$ levels are related to an improved clinical outcome. This suggests that some of the sHLA- $\mathrm{G}_{\text {free }}$ molecules are impaired regarding LILRB1 recognition, and thereby are not qualified to exert inhibitory functions, as already demonstrated in rheumatoid arthritis patients (83). In conclusion, this study exemplifies the importance of stratifying soluble forms of HLA-G into free and EVs-bound molecules, as these two subcomponents can display diametrically opposed prognostic impact on disease progression likely due to the differential power of these compounds to contribute to an immune escape of tumor cells.

Further underlining the functional relevance of HLA-Gbearing EVs in cancer, a recent study demonstrated that (i) EVs released by renal cancer stem cells carry HLA-G with a HLA-G1 typical molecular weight, (ii) these HLA-G-bearing EVs impair the differentiation of monocytes to mature DCs, and (iii) the presence of these DCs reduces the $\mathrm{T}$ cell proliferation. Thus, HLA-G-bearing EVs mediate inhibitory effects on monocyte differentiation and their maturation to DCs (84).

\section{HLA-G-Bearing EVs and Pregnancy}

At the maternal-fetal interface, HLA-G and its soluble forms are expressed on both sides, on extravillous trophoblast cells lining the placenta and on tolerance-inducing DCs (DC-10) being enriched in the first trimester decidua $(25,85)$. Thus, HLA-G is thought to orchestrate the cross talk among embryo trophoblasts, decidual leukocytes, and stromal cells allowing the trophoblast invasiveness, decidual cell differentiation, vascular remodeling, and the reprograming of local maternal immune responses (86). Whether HLA-G-bearing EVs represent an additional instrument to mediate communication of these cells is currently unclear. Interestingly, both first trimester and term placentas have been reported to secrete HLA-G5 isoforms via EVs (87). In agreement with the reported immunolocalization of HLA-G (88) cytotrophoblast cells, but not differentiated syncytiotroblasts, are producing HLA-G5-positive exosomes. The observation of the presence of HLA-G5 in EVs raises the issue whether HLA-G5 is associated with the luminal or with the extravesicular EV side. As secreted molecules, the association of HLA-G5 with extravesicular EV sides would require a binding partner it can associate with. Alternatively, the association with the luminal side would require the transit of HLA-G into the cytoplasma after biosynthesis. Independently of the immunogenicity of EVs and of the secretion pathway directing HLA-G5 toward EVs, it is clear that HLA-G5 isoforms being inside of EVs are hidden, which provokes questions about the function of HLA-G5 in cytotrophoblast-derived EVs.

\section{HLA-G-Bearing EVs and Mesenchymal Stem/Stromal Cells}

Similar to trophoblast cells, mesenchymal stem/stromal cells (MSCs) express surface-expressed and soluble forms of HLA-G, which are involved in the suppression of $\mathrm{T}$ and NK cell functions (89). Besides HLA-G, MSCs exert the immune regulatory and modulatory activities through a variety of soluble mediators such as IL10, TGF $\beta$, either as free soluble molecules or via immunological active EVs (90). The latter have been suggested to mediate synergistical effects of these molecules. In view of this, MSC-derived EVs, containing huge amounts of HLA-G, IL-10 and TGF $\beta$, were used to treat a patient suffering from severe and therapy-refractory cutaneous and intestinal GvHD grade IV (91). After serial application rounds of MSC-EVs, a substantial improvement of the clinical GvHD symptoms has been achieved without any side-effects. Simultaneously, the allogeneic cytokine responsiveness of the patient's peripheral mononuclear blood cells was substantially reduced. Although a direct impact of HLA-G on the immune suppression has not been demonstrated, this study represents the first treatment in humans, in which HLA-G with the immune modulatory function of MSC-derived EVs has been applied. Thus, it triggered significant interest in applying EVsbased therapeutics in clinical trials (92).

\section{New Perspectives of HLA-G-Bearing Extracellular Vesicles}

Currently, the known functions of HLA-G are restricted to receptors expressed on the surface of effector cells of the innate and adaptive immune system. In this way, HLA-G inhibits the cytolytic function of NK cells $(93,94)$, the antigen-specific cytolytic function of cytotoxic T lymphocytes (CTL) (95) and $\gamma / \delta \mathrm{T}$ cells (96), the allogeneic proliferative response (95), and proliferation of CD4+ T cells (97). HLA-G also impairs the maturation and function of DC $(98,99)$. Furthermore, HLA-G is related to regulatory cells including regulatory $\mathrm{T}$ cells $(89,100-102)$, regulatory DC (103), and myeloid-derived suppressor cells (104). Due to the differential composition of EVs, other compounds of the EVs may potentiate or abrogate the functional power of HLA-G. 
Additionally, EVs harboring HLA-G may allow the interaction with target cells lacking the surface expression of HLA-G specific receptors.

Membrane fusion of EVs to target cells can represent a possible mode of how HLA-G can be transferred to target cells. In this context, it is noteworthy that a cellular translocation of HLA-G from APCs to activated T cells (102) and from tumor cells to T/NK cells has been reported $(105,106)$. The acquisition of HLA-G reverses the function of $\mathrm{T}$ and NK cells to regulatory cells impairing allo-immune responsiveness. Such a spatiotemporal mechanism is suggested to be an instrument for "emergency" immune suppression used by HLA-G-expressing tissues to protect themselves against aggressive immune intervention (102). It is tempting to speculate that EVs mediate a transfer of HLA-G to effector cells, which would abrogate at least the regional mode of action.

Independent of the pathway, internalization of HLA-G-bearing EVs provides the opportunity for HLA-G to participate in yet unknown intracellular pathways. Interestingly, both soluble HLAG5 and shed HLA-G1 have been reported to be bound by the transiently expressed KIR2DL4 receptor and to be endocytosed into early endosomes of NK cells (107-109). This leads to the activation of a nuclear factor- $\mathrm{\kappa B}$-pathway and finally to the transcription of pro-inflammatory and proangiogenic factors. Thus, the sustained endosomal signaling by KIR2DL4/HLA-G may allow NK cell activation despite a potential dominant inhibitory receptor-ligand interaction at cell surface. In context with the secretion of HLA-G by fetal trophoblast cells, this NK cell-mediated mechanism has been discussed to be operative in the promotion of vascularization in maternal decidua during early pregnancy (107-109). Here the question arises, whether this KIR2DL4HLA-G pathway becomes operative when fetal trophoblast cells secrete HLA-G-bearing EVs or whether other yet unknown receptors can mediate intercellular signaling. The investigation of molecular signature molecules on HLA-G-bearing EVs may help to provide an insight into the functional consequence and the intracellular signaling pathway after internalization (69).

Regarding the role of HLA-G in diagnosis, prognosis, and treatment, the cell-specific signature of HLA-G-bearing EVs may not only provide information about the potential target cells and about its potential interplay of the cognate receptor/ligand on target cells but also about the cells producing these EVs (110). In that

\section{REFERENCES}

1. Carosella ED, Favier B, Rouas-Freiss N, Moreau P, Lemaoult J. Beyond the increasing complexity of the immunomodulatory HLA-G molecule. Blood (2008) 111(10):4862-70. doi:10.1182/blood-2007-12-127662

2. Rebmann V, Pfeiffer K, Passler M, Ferrone S, Maier S, Weiss E, et al. Detection of soluble HLA-G molecules in plasma and amniotic fluid. Tissue Antigens (1999) 53(1):14-22. doi:10.1034/j.1399-0039.1999.530102.x

3. Singer G, Rebmann V, Chen YC, Liu HT, Ali SZ, Reinsberg J, et al. HLA-G is a potential tumor marker in malignant ascites. Clin Cancer Res (2003) 9(12):4460-4.

4. Zilberman S, Schenowitz C, Agaugue S, Benoit F, Riteau B, Rouzier R, et al. HLA-G1 and HLA-G5 active dimers are present in malignant cells and effusions: the influence of the tumor microenvironment. Eur J Immunol (2012) 42(6):1599-608. doi:10.1002/eji.201141761

5. Davidson B, Elstrand MB, McMaster MT, Berner A, Kurman RJ, Risberg B, et al. HLA-G expression in effusions is a possible marker of tumor way, the identification of the cellular source on HLA-G-bearing EVs, such as the detection of the tumor marker HER-2/neu, may offer unforeseen diagnostic opportunities to monitor the systemic health status/disease status and disease activity/progression.

\section{CONCLUSION}

It is well established that tumor cells, cytotrophoblast cells, and MSCs secret HLA-G-bearing EVs in addition to non-vesicular soluble HLA-G. All of these cell types are highly capable of promoting immune tolerance and tissue remodeling. Mechanisms and functional consequences of HLA-G-bearing EVs and their specific contribution to the biology of these cells have yet to be determined. So far, the classical concept of HLA-G function is based on the interaction of HLA-G with receptors being expressed on the cell surface membrane. EVs, however, may serve as a ticket for HLA-G to interact directly with cells or to enter into the inside of cells. The internalization of HLA-G may introduce new pathways or yet unknown cognate receptors, by which HLA-G contributes to intracellular communication. In that way, HLA-Gbearing EVs are likely to represent an important element in the biology of HLA-G.

\section{AUTHOR CONTRIBUTIONS}

VR: concept and design, drafting of manuscript. VR and $\mathrm{PH}$ : critical revision of the manuscript for important intellectual points, supervision. LK, FN, BW, LM, VR, and PH: drafting of manuscript.

\section{ACKNOWLEDGMENTS}

This work was supported by IFORES (D/107-81080), University of Duisburg-Essen, and by Deutsche Krebshilfe (109816).

\section{FUNDING}

This work was partly supported by research Ph.D. scholarship funding from CAPES Foundation, Ministry of Education of Brazil, Brasília - DF 70.040-020, Brazil.

susceptibility to chemotherapy in ovarian carcinoma. Gynecol Oncol (2005) 96(1):42-7. doi:10.1016/j.ygyno.2004.09.049

6. Fainardi E, Bortolotti D, Bolzani S, Castellazzi M, Tamborino C, Roversi G, et al. Cerebrospinal fluid amounts of HLA-G in dimeric form are strongly associated to patients with MRI inactive multiple sclerosis. Mult Scler (2016) 22(2):245-9. doi:10.1177/1352458515590647

7. Morandi F, Venturi C, Rizzo R, Castellazzi M, Baldi E, Caniatti ML, et al. Intrathecal soluble HLA-E correlates with disease activity in patients with multiple sclerosis and may cooperate with soluble HLA-G in the resolution of neuroinflammation. J Neuroimmune Pharmacol (2013) 8(4):944-55. doi:10.1007/s11481-013-9459-3

8. Yao GD, Shu YM, Shi SL, Peng ZF, Song WY, Jin HX, et al. Expression and potential roles of HLA-G in human spermatogenesis and early embryonic development. PLoS One (2014) 9(3):e92889. doi:10.1371/journal. pone.0092889

9. Paul P, Rouas-Freiss N, Khalil-Daher I, Moreau P, Riteau B, Le Gal FA, et al. HLA-G expression in melanoma: a way for tumor cells to escape 
from immunosurveillance. Proc Natl Acad Sci U S A (1998) 95(8):4510-5. doi:10.1073/pnas.95.8.4510

10. Curigliano G, Criscitiello C, Gelao L, Goldhirsch A. Molecular pathways: human leukocyte antigen G (HLA-G). Clin Cancer Res (2013) 19(20):556471. doi:10.1158/1078-0432.CCR-12-3697

11. Rouas-Freiss N, Moreau P, Menier C, LeMaoult J, Carosella ED. Expression of tolerogenic HLA-G molecules in cancer prevents antitumor responses. Semin Cancer Biol (2007) 17(6):413-21. doi:10.1016/j.semcancer.2007.07.003

12. Lin A, Chen HX, Zhu CC, Zhang X, Xu HH, Zhang JG, et al. Aberrant human leucocyte antigen-G expression and its clinical relevance in hepatocellular carcinoma. J Cell Mol Med (2010) 14(8):2162-71. doi:10.1111/j.1582-4934.2009.00917.x

13. Wang Y, Ye Z, Meng XQ, Zheng SS. Expression of HLA-G in patients with hepatocellular carcinoma. Hepatobiliary Pancreat Dis Int (2011) 10(2):15863. doi:10.1016/S1499-3872(11)60025-8

14. Onno M, Pangault C, Le Friec G, Guilloux V, Andre P, Fauchet R. Modulation of HLA-G antigens expression by human cytomegalovirus: specific induction in activated macrophages harboring human cytomegalovirus infection. J Immunol (2000) 164(12):6426-34. doi:10.4049/jimmunol.164.12.6426

15. Carosella ED, Moreau P, Aractingi S, Rouas-Freiss N. HLA-G: a shield against inflammatory aggression. Trends Immunol (2001) 22(10):553-5. doi:10.1016/ S1471-4906(01)02007-5

16. Souto FJ, Crispim JC, Ferreira SC, da Silva AS, Bassi CL, Soares CP, et al. Liver HLA-G expression is associated with multiple clinical and histopathological forms of chronic hepatitis B virus infection. J Viral Hepat (2011) 18(2):102-5. doi:10.1111/j.1365-2893.2010.01286.x

17. Rodriguez JA, Galeano L, Palacios DM, Gomez C, Serrano ML, Bravo MM, et al. Altered HLA class I and HLA-G expression is associated with IL-10 expression in patients with cervical cancer. Pathobiology (2012) 79(2):72-83. doi:10.1159/000334089

18. Amiot L, Vu N, Rauch M, L'Helgoualc'h A, Chalmel F, Gascan H, et al. Expression of HLA-G by mast cells is associated with hepatitis Cvirus-induced liver fibrosis. J Hepatol (2014) 60(2):245-52. doi:10.1016/j.jhep.2013.09.006

19. Amiot L, Vu N, Samson M. Immunomodulatory properties of HLA-G in infectious diseases. J Immunol Res (2014) 2014:298569. doi:10.1155/2014/298569

20. Rizzo R, Hviid TV, Govoni M, Padovan M, Rubini M, Melchiorri L, et al. HLA-G genotype and HLA-G expression in systemic lupus erythematosus: HLA-G as a putative susceptibility gene in systemic lupus erythematosus. Tissue Antigens (2008) 71(6):520-9. doi:10.1111/j.1399-0039.2008.01037.x

21. Verbruggen LA, Rebmann V, Demanet C, De Cock S, Grosse-Wilde H. Soluble HLA-G in rheumatoid arthritis. Hum Immunol (2006) 67(8):561-7. doi:10.1016/j.humimm.2006.03.023

22. Brenol CV, Veit TD, Chies JA, Xavier RM. The role of the HLA-G gene and molecule on the clinical expression of rheumatologic diseases. Rev Bras Reumatol (2012) 52(1):82-91. doi:10.1590/S0482-50042012000100009

23. Rizzo R, Bortolotti D, Baricordi OR, Fainardi E. New insights into HLA-G and inflammatory diseases. Inflamm Allergy Drug Targets (2012) 11(6):448-63. doi:10.2174/187152812803590037

24. Hviid TV. HLA-G in human reproduction: aspects of genetics, function and pregnancy complications. Hum Reprod Update (2006) 12(3):209-32. doi:10.1093/humupd/dmi048

25. Rizzo R, Vercammen M, van de Velde H, Horn PA, Rebmann V. The importance of HLA-G expression in embryos, trophoblast cells, and embryonic stem cells. Cell Mol Life Sci (2011) 68(3):341-52. doi:10.1007/s00018-010-0578-1

26. Lila N, Carpentier A, Amrein C, Khalil-Daher I, Dausset J, Carosella ED. Implication of HLA-G molecule in heart-graft acceptance. Lancet (2000) 355(9221):2138. doi:10.1016/S0140-6736(00)02386-2

27. Deschaseaux F, Delgado D, Pistoia V, Giuliani M, Morandi F, Durrbach A. HLA-G in organ transplantation: towards clinical applications. Cell Mol Life Sci (2011) 68(3):397-404. doi:10.1007/s00018-010-0581-6

28. HoWangYin KY, Loustau M, Wu J, Alegre E, Daouya M, Caumartin J, et al. Multimeric structures of HLA-G isoforms function through differential binding to LILRB receptors. Cell Mol Life Sci (2012) 69(23):4041-9. doi:10.1007/ s00018-012-1069-3

29. Boyson JE, Erskine R, Whitman MC, Chiu M, Lau JM, Koopman LA, et al. Disulfide bond-mediated dimerization of HLA-G on the cell surface. Proc Natl Acad Sci U S A (2002) 99(25):16180-5. doi:10.1073/pnas.212643199
30. Gonen-Gross T, Achdout H, Gazit R, Hanna J, Mizrahi S, Markel G, et al. Complexes of HLA-G protein on the cell surface are important for leukocyte Ig-like receptor-1 function. J Immunol (2003) 171(3):1343-51. doi:10.4049/ jimmunol.171.3.1343

31. Park GM, Lee S, Park B, Kim E, Shin J, Cho K, et al. Soluble HLA-G generated by proteolytic shedding inhibits NK-mediated cell lysis. Biochem Biophys Res Commun (2004) 313(3):606-11. doi:10.1016/j.bbrc.2003.11.153

32. Riteau B, Faure F, Menier C, Viel S, Carosella ED, Amigorena S, et al. Exosomes bearing HLA-G are released by melanoma cells. Hum Immunol (2003) 64(11):1064-72. doi:10.1016/j.humimm.2003.08.344

33. Shiroishi M, Kuroki K, Rasubala L, Tsumoto K, Kumagai I, Kurimoto E, et al. Structural basis for recognition of the nonclassical MHC molecule HLA-G by the leukocyte Ig-like receptor B2 (LILRB2/LIR2/ILT4/CD85d). Proc Natl Acad Sci U S A (2006) 103(44):16412-7. doi:10.1073/pnas.0605228103

34. Gonen-Gross T, Achdout H, Arnon TI, Gazit R, Stern N, Horejsi V, et al. The CD85J/leukocyte inhibitory receptor-1 distinguishes between conformed and beta 2-microglobulin-free HLA-G molecules. J Immunol (2005) 175(8):4866-74. doi:10.4049/jimmunol.175.8.4866

35. Apps R, Gardner L, Sharkey AM, Holmes N, Moffett A. A homodimeric complex of HLA-G on normal trophoblast cells modulates antigen-presenting cells via LILRB1. Eur J Immunol (2007) 37(7):1924-37. doi:10.1002/ eji.200737089

36. Shiroishi M, Kuroki K, Ose T, Rasubala L, Shiratori I, Arase H, et al. Efficient leukocyte Ig-like receptor signaling and crystal structure of disulfide-linked HLA-G dimer. J Biol Chem (2006) 281(15):10439-47. doi:10.1074/jbc. M512305200

37. Contini P, Ghio M, Poggi A, Filaci G, Indiveri F, Ferrone S, et al. Soluble HLA-A,-B,-C and -G molecules induce apoptosis in T and NK CD8+ cells and inhibit cytotoxic T cell activity through CD8 ligation. Eur J Immunol (2003) 33(1):125-34. doi:10.1002/immu.200390015

38. Fons P, Chabot S, Cartwright JE, Lenfant F, L'Faqihi F, Giustiniani J, et al. Soluble HLA-G1 inhibits angiogenesis through an apoptotic pathway and by direct binding to CD160 receptor expressed by endothelial cells. Blood (2006) 108(8):2608-15. doi:10.1182/blood-2005-12-019919

39. Carosella ED, Rouas-Freiss N, Roux DT, Moreau P, LeMaoult J. HLA-G: an immune checkpoint molecule. Adv Immunol (2015) 127:33-144. doi:10.1016/ bs.ai.2015.04.001

40. Yanez-Mo M, Siljander PR, Andreu Z, Zavec AB, Borras FE, Buzas EI, et al. Biological properties of extracellular vesicles and their physiological functions. J Extracell Vesicles (2015) 4:27066. doi:10.3402/ jev.v4.27066

41. Colombo M, Raposo G, Thery C. Biogenesis, secretion, and intercellular interactions of exosomes and other extracellular vesicles. Annu Rev Cell Dev Biol (2014) 30:255-89. doi:10.1146/annurev-cellbio-101512-122326

42. Di Vizio D, Kim J, Hager MH, Morello M, Yang W, Lafargue CJ, et al. Oncosome formation in prostate cancer: association with a region of frequent chromosomal deletion in metastatic disease. Cancer Res (2009) 69(13):5601-9. doi:10.1158/0008-5472.CAN-08-3860

43. Sokolova V, Ludwig AK, Hornung S, Rotan O, Horn PA, Epple M, et al. Characterisation of exosomes derived from human cells by nanoparticle tracking analysis and scanning electron microscopy. Colloids Surf B Biointerfaces (2011) 87(1):146-50. doi:10.1016/j.colsurfb. 2011.05.013

44. Lotvall J, Hill AF, Hochberg F, Buzas EI, Di Vizio D, Gardiner C, et al. Minimal experimental requirements for definition of extracellular vesicles and their functions: a position statement from the International Society for Extracellular Vesicles. J Extracell Vesicles (2014) 3:26913. doi:10.3402/jev. v3.26913

45. Zhang HG, Zhuang X, Sun D, Liu Y, Xiang X, Grizzle WE. Exosomes and immune surveillance of neoplastic lesions: a review. Biotech Histochem (2012) 87(3):161-8. doi:10.3109/10520291003659042

46. Vlassov AV, Magdaleno S, Setterquist R, Conrad R. Exosomes: current knowledge of their composition, biological functions, and diagnostic and therapeutic potentials. Biochim Biophys Acta (2012) 1820(7):940-8. doi:10.1016/j.bbagen.2012.03.017

47. van Dommelen SM, Vader P, Lakhal S, Kooijmans SA, van Solinge WW, Wood MJ, et al. Microvesicles and exosomes: opportunities for cell-derived 
membrane vesicles in drug delivery. J Control Release (2012) 161(2):635-44. doi:10.1016/j.jconrel.2011.11.021

48. Kharaziha P, Ceder S, Li Q, Panaretakis T. Tumor cell-derived exosomes: a message in a bottle. Biochim Biophys Acta (2012) 1826(1):103-11. doi:10.1016/j.bbcan.2012.03.006

49. Gauvreau ME, Cote MH, Bourgeois-Daigneault MC, Rivard LD, Xiu F, Brunet A, et al. Sorting of MHC class II molecules into exosomes through a ubiquitin-independent pathway. Traffic (2009) 10(10):1518-27. doi:10.1111/j.1600-0854.2009.00948.x

50. Arita S, Baba E, Shibata Y, Niiro H, Shimoda S, Isobe T, et al. B cell activation regulates exosomal HLA production. Eur J Immunol (2008) 38(5):1423-34. doi:10.1002/eji.200737694

51. Clayton A, Court J, Navabi H, Adams M, Mason MD, Hobot JA, et al. Analysis of antigen presenting cell derived exosomes, based on immuno-magnetic isolation and flow cytometry. J Immunol Methods (2001) 247(1-2):163-74. doi:10.1016/S0022-1759(00)00321-5

52. Raposo G, Nijman HW, Stoorvogel W, Liejendekker R, Harding CV, Melief CJ, et al. B lymphocytes secrete antigen-presenting vesicles. J Exp Med (1996) 183(3):1161-72. doi:10.1084/jem.183.3.1161

53. Alegre E, Rebmann V, Lemaoult J, Rodriguez C, Horn PA, Diaz-Lagares A, et al. In vivo identification of an HLA-G complex as ubiquitinated protein circulating in exosomes. Eur J Immunol (2013) 43(7):1933-9. doi:10.1002/ eji.201343318

54. Subra C, Grand D, Laulagnier K, Stella A, Lambeau G, Paillasse M, et al. Exosomes account for vesicle-mediated transcellular transport of activatable phospholipases and prostaglandins. JLipid Res (2010) 51(8):2105-20. doi:10.1194/jlr.M003657

55. Esser J, Gehrmann U, D’Alexandri FL, Hidalgo-Estevez AM, Wheelock CE, Scheynius A, et al. Exosomes from human macrophages and dendritic cells contain enzymes for leukotriene biosynthesis and promote granulocyte migration. JAllergy Clin Immunol (2010) 126(5):.e1-4. doi:10.1016/j. jaci.2010.06.039

56. Ela S, Mager I, Breakefield XO, Wood MJ. Extracellular vesicles: biology and emerging therapeutic opportunities. Nat Rev Drug Discov (2013) 12(5):347-57. doi:10.1038/nrd3978

57. Valadi H, Ekstrom K, Bossios A, Sjostrand M, Lee JJ, Lotvall JO. Exosomemediated transfer of mRNAs and microRNAs is a novel mechanism of genetic exchange between cells. Nat Cell Biol (2007) 9(6):654-9. doi:10.1038/ ncb1596

58. Mittelbrunn M, Gutierrez-Vazquez C, Villarroya-Beltri C, Gonzalez S, Sanchez-Cabo F, Gonzalez MA, et al. Unidirectional transfer of microRNA-loaded exosomes from T cells to antigen-presenting cells. Nat Commun (2011) 2:282. doi:10.1038/ncomms1285

59. Ludwig AK, Giebel B. Exosomes: small vesicles participating in intercellular communication. Int J Biochem Cell Biol (2012) 44(1):11-5. doi:10.1016/ j.biocel.2011.10.005

60. Mack M, Kleinschmidt A, Bruhl H, Klier C, Nelson PJ, Cihak J, et al. Transfer of the chemokine receptor CCR5 between cells by membrane-derived microparticles: a mechanism for cellular human immunodeficiency virus 1 infection. Nat Med (2000) 6(7):769-75. doi:10.1038/77498

61. Al-Nedawi K, Meehan B, Micallef J, Lhotak V, May L, Guha A, et al. Intercellular transfer of the oncogenic receptor EGFRvIII by microvesicles derived from tumour cells. Nat Cell Biol (2008) 10(5):619-24. doi:10.1038/ ncb1725

62. Laulagnier K, Grand D, Dujardin A, Hamdi S, Vincent-Schneider H, Lankar D, et al. PLD2 is enriched on exosomes and its activity is correlated to the release of exosomes. FEBS Lett (2004) 572(1-3):11-4. doi:10.1016/ j.febslet.2004.06.082

63. Laulagnier K, Motta C, Hamdi S, Roy S, Fauvelle F, Pageaux JF, et al. Mast cell- and dendritic cell-derived exosomes display a specific lipid composition and an unusual membrane organization. Biochem J (2004) 380(Pt 1):161-71. doi:10.1042/BJ20031594

64. Parolini I, Federici C, Raggi C, Lugini L, Palleschi S, De Milito A, et al. Microenvironmental $\mathrm{pH}$ is a key factor for exosome traffic in tumor cells. J Biol Chem (2009) 284(49):34211-22. doi:10.1074/jbc.M109.041152

65. Subra C, Laulagnier K, Perret B, Record M. Exosomelipidomics unravels lipid sorting at the level of multivesicular bodies. Biochimie (2007) 89(2):205-12. doi:10.1016/j.biochi.2006.10.014
66. Record M, Carayon K, Poirot M, Silvente-Poirot S. Exosomes as new vesicular lipid transporters involved in cell-cell communication and various pathophysiologies. Biochim Biophys Acta (2014) 1841(1):108-20. doi:10.1016/ j.bbalip.2013.10.004

67. Mulcahy LA, Pink RC, Carter DR. Routes and mechanisms of extracellular vesicle uptake. J Extracell Vesicles (2014) 3:24641. doi:10.3402/jev.v3.24641

68. Buschow SI, Nolte-'t Hoen EN, van Niel G, Pols MS, ten Broeke T, Lauwen M, et al. MHC II in dendritic cells is targeted to lysosomes or T cell-induced exosomes via distinct multivesicular body pathways. Traffic (2009) 10(10):1528-42. doi:10.1111/j.1600-0854.2009.00963.x

69. Nolte-'t Hoen EN, Buschow SI, Anderton SM, Stoorvogel W, Wauben MH. Activated T cells recruit exosomes secreted by dendritic cells via LFA-1. Blood (2009) 113(9):1977-81. doi:10.1182/blood-2008-08-174094

70. Saunderson SC, Schuberth PC, Dunn AC, Miller L, Hock BD, MacKay PA, et al. Induction of exosome release in primary B cells stimulated via CD40 and the IL-4 receptor. JImmunol (2008) 180(12):8146-52. doi:10.4049/ jimmunol.180.12.8146

71. Arnold PY, Mannie MD. Vesicles bearing MHC class II molecules mediate transfer of antigen from antigen-presenting cells to CD4+ T cells. Eur JImmunol (1999) 29(4):1363-73. doi:10.1002/ (SICI)1521-4141(199904)29:04<1363::AID-IMMU1363>3.0.CO;2-0

72. Admyre C, Grunewald J, Thyberg J, Gripenback S, Tornling G, Eklund A, et al. Exosomes with major histocompatibility complex class II and co-stimulatory molecules are present in human BAL fluid. Eur Respir J (2003) 22(4):578-83. doi:10.1183/09031936.03.00041703

73. Thery C, Duban L, Segura E, Veron P, Lantz O, Amigorena S. Indirect activation of naive CD4+ T cells by dendritic cell-derived exosomes. Nat Immunol (2002) 3(12):1156-62. doi:10.1038/ni854

74. Guermonprez P, Valladeau J, Zitvogel L, Thery C, Amigorena S. Antigen presentation and T cell stimulation by dendritic cells. Annu Rev Immunol (2002) 20:621-67. doi:10.1146/annurev.immunol.20.100301.064828

75. Thery C, Ostrowski M, Segura E. Membrane vesicles as conveyors of immune responses. Nat Rev Immunol (2009) 9(8):581-93. doi:10.1038/nri2567

76. Muturi HT, Dreesen JD, Nilewski E, Jastrow H, Giebel B, Ergun S, et al. Tumor and endothelial cell-derived microvesicles carry distinct CEACAMs and influence T-cell behavior. PLoS One (2013) 8(9):e74654. doi:10.1371/ journal.pone. 0074654

77. Abusamra AJ, Zhong Z, Zheng X, Li M, Ichim TE, Chin JL, et al. Tumor exosomes expressing Fas ligand mediate CD8+ T-cell apoptosis. Blood Cells Mol Dis (2005) 35(2):169-73. doi:10.1016/j.bcmd.2005.07.001

78. Wieckowski EU, Visus C, Szajnik M, Szczepanski MJ, Storkus WJ, Whiteside TL. Tumor-derived microvesicles promote regulatory $\mathrm{T}$ cell expansion and induce apoptosis in tumor-reactive activated CD8+ T lymphocytes. J Immunol (2009) 183(6):3720-30. doi:10.4049/jimmunol.0900970

79. Duncan LM, Piper S, Dodd RB, Saville MK, Sanderson CM, Luzio JP, et al. Lysine-63-linked ubiquitination is required for endolysosomal degradation of class I molecules. EMBO J (2006) 25(8):1635-45. doi:10.1038/ sj.emboj.7601056

80. Boname JM, Thomas M, Stagg HR, Xu P, Peng J, Lehner PJ. Efficient internalization of MHC I requires lysine- 11 and lysine- 63 mixed linkage polyubiquitin chains. Traffic (2010) 11(2):210-20. doi:10.1111/j.1600-0854.2009.01011.x

81. Buschow SI, Liefhebber JM, Wubbolts R, Stoorvogel W. Exosomes contain ubiquitinated proteins. Blood Cells Mol Dis (2005) 35(3):398-403. doi:10.1016/j.bcmd.2005.08.005

82. Konig L, Kasimir-Bauer S, Hoffmann O, Bittner AK, Wagner B, Manvailer LF, et al. The prognostic impact of soluble and vesicular HLA-G and its relationship to circulating tumor cells in neoadjuvant treated breast cancer patients. Hum Immunol (2016). doi:10.1016/j.humimm.2016.01.002

83. Veit TD, Chies JA, Switala M, Wagner B, Horn PA, Busatto M, et al. The paradox of high availability and low recognition of soluble HLA-G by LILRB1 receptor in rheumatoid arthritis patients. PLoS One (2015) 10(4):e0123838. doi:10.1371/journal.pone.0123838

84. Grange C, Tapparo M, Tritta S, Deregibus MC, Battaglia A, Gontero P, et al. Role of HLA-G and extracellular vesicles in renal cancer stem cell-induced inhibition of dendritic cell differentiation. BMC Cancer (2015) 15(1):1009. doi:10.1186/s12885-015-2025-Z

85. Amodio G, Mugione A, Sanchez AM, Vigano P, Candiani M, Somigliana E, et al. HLA-G expressing DC-10 and CD4(+) T cells accumulate in human 
decidua during pregnancy. Hum Immunol (2013) 74(4):406-11. doi:10.1016/j. humimm.2012.11.031

86. Gregori S, Amodio G, Quattrone F, Panina-Bordignon P. HLA-G orchestrates the early interaction of human trophoblasts with the maternal niche. Front Immunol (2015) 6:128. doi:10.3389/fimmu.2015.00128

87. Kshirsagar SK, Alam SM, Jasti S, Hodes H, Nauser T, Gilliam M, et al. Immunomodulatory molecules are released from the first trimester and term placenta via exosomes. Placenta (2012) 33(12):982-90. doi:10.1016/j. placenta.2012.10.005

88. Morales PJ, Pace JL, Platt JS, Langat DK, Hunt JS. Synthesis of beta(2)microglobulin-free, disulphide-linked HLA-G5 homodimers in human placental villous cytotrophoblast cells. Immunology (2007) 122(2):179-88. doi:10.1111/j.1365-2567.2007.02623.x

89. Selmani Z, Naji A, Zidi I, Favier B, Gaiffe E, Obert L, et al. Human leukocyte antigen-G5 secretion by human mesenchymal stem cells is required to suppress $\mathrm{T}$ lymphocyte and natural killer function and to induce CD4+CD25highFOXP3+ regulatory T cells. Stem Cells (2008) 26(1):212-22. doi:10.1634/stemcells.2007-0554

90. Zhang B, Yin Y, Lai RC, Tan SS, Choo AB, Lim SK. Mesenchymal stem cells secrete immunologically active exosomes. Stem Cells Dev (2014) 23(11):1233-44. doi:10.1089/scd.2013.0479

91. Kordelas L, Rebmann V, Ludwig AK, Radtke S, Ruesing J, Doeppner TR, et al. MSC-derived exosomes: a novel tool to treat therapy-refractory graft-versushost disease. Leukemia (2014) 28(4):970-3. doi:10.1038/leu.2014.41

92. Lener T, Gimona M, Aigner L, Borger V, Buzas E, Camussi G, et al. Applying extracellular vesicles based therapeutics in clinical trials - an ISEV position paper. J Extracell Vesicles (2015) 4:30087. doi:10.3402/jev.v4.30087

93. Rouas-Freiss N, Goncalves RM, Menier C, Dausset J, Carosella ED. Direct evidence to support the role of HLA-G in protecting the fetus from maternal uterine natural killer cytolysis. Proc Natl Acad Sci U S A (1997) 94(21):11520-5. doi:10.1073/pnas.94.21.11520

94. Lin A, Xu HH, Xu DP, Zhang X, Wang Q, Yan WH. Multiple steps of HLA-G in ovarian carcinoma metastasis: alter NK cytotoxicity and induce matrix metalloproteinase-15 (MMP-15) expression. Hum Immunol (2013) 74(4):439-46. doi:10.1016/j.humimm.2012.11.021

95. Le Gal FA, Riteau B, Sedlik C, Khalil-Daher I, Menier C, Dausset J, et al. HLA-G-mediated inhibition of antigen-specific cytotoxic T lymphocytes. Int Immunol (1999) 11(8):1351-6. doi:10.1093/intimm/11.8.1351

96. Lesport E, Baudhuin J, Sousa S, LeMaoult J, Zamborlini A, Rouas-Freiss N, et al. Inhibition of human gamma delta [corrected] T-cell antitumoral activity through HLA-G: implications for immunotherapy of cancer. Cell Mol Life Sci (2011) 68(20):3385-99. doi:10.1007/s00018-011-0632-7

97. Bainbridge DR, Ellis SA, Sargent IL. HLA-G suppresses proliferation of CD4(+) T-lymphocytes. J Reprod Immunol (2000) 48(1):17-26. doi:10.1016/ S0165-0378(00)00070-X

98. Ristich V, Liang S, Zhang W, Wu J, Horuzsko A. Tolerization of dendritic cells by HLA-G. Eur J Immunol (2005) 35(4):1133-42. doi:10.1002/eji.200425741

99. Gros F, Cabillic F, Toutirais O, Maux AL, Sebti Y, Amiot L. Soluble HLA-G molecules impair natural killer/dendritic cell crosstalk via inhibition of dendritic cells. Eur J Immunol (2008) 38(3):742-9. doi:10.1002/eji.200736918
100. LeMaoult J, Krawice-Radanne I, Dausset J, Carosella ED. HLA-G1-expressing antigen-presenting cells induce immunosuppressive CD4+ T cells. Proc Natl Acad Sci U S A (2004) 101(18):7064-9. doi:10.1073/pnas.0401922101

101. Le Rond S, Azema C, Krawice-Radanne I, Durrbach A, Guettier C, Carosella ED, et al. Evidence to support the role of HLA-G5 in allograft acceptance through induction of immunosuppressive/regulatory $\mathrm{T}$ cells. J Immunol (2006) 176(5):3266-76. doi:10.4049/jimmunol.176.5.3266

102. Naji A, Le Rond S, Durrbach A, Krawice-Radanne I, Creput C, Daouya M, et al. CD3+CD4low and CD3+CD8low are induced by HLA-G: novel human peripheral blood suppressor T-cell subsets involved in transplant acceptance. Blood (2007) 110(12):3936-48. doi:10.1182/blood-2007-04-083139

103. Gregori S, Tomasoni D, Pacciani V, Scirpoli M, Battaglia M, Magnani CF, et al. Differentiation of type $1 \mathrm{~T}$ regulatory cells $(\mathrm{Tr} 1)$ by tolerogenic DC-10 requires the IL-10-dependent ILT4/HLA-G pathway. Blood (2010) 116(6):935-44. doi:10.1182/blood-2009-07-234872

104. Agaugue S, Carosella ED, Rouas-Freiss N. Role of HLA-G in tumor escape through expansion of myeloid-derived suppressor cells and cytokinic balance in favor of Th2 versus Th1/Th17. Blood (2011) 117(26):7021-31. doi:10.1182/ blood-2010-07-294389

105. Brown R, Kabani K, Favaloro J, Yang S, Ho PJ, Gibson J, et al. CD86+ or HLA$\mathrm{G}+$ can be transferred via trogocytosis from myeloma cells to $\mathrm{T}$ cells and are associated with poor prognosis. Blood (2012) 120(10):2055-63. doi:10.1182/ blood-2012-03-416792

106. Caumartin J, Favier B, Daouya M, Guillard C, Moreau P, Carosella ED, et al. Trogocytosis-based generation of suppressive NK cells. EMBO J (2007) 26(5):1423-33. doi:10.1038/sj.emboj.7601570

107. Rajagopalan S. HLA-G-mediated NK cell senescence promotes vascular remodeling: implications for reproduction. Cell Mol Immunol (2014) 11(5):460-6. doi:10.1038/cmi.2014.53

108. Rajagopalan S, Bryceson YT, Kuppusamy SP, Geraghty DE, van der Meer A, Joosten I, et al. Activation of NK cells by an endocytosed receptor for soluble HLA-G. PLoS Biol (2006) 4(1):e9. doi:10.1371/journal.pbio.0040009

109. Rajagopalan S, Long EO. KIR2DL4 (CD158d): an activation receptor for HLA-G. Front Immunol (2012) 3:258. doi:10.3389/fimmu.2012.00258

110. Choudhuri K, Llodra J, Roth EW, Tsai J, Gordo S, Wucherpfennig KW, et al. Polarized release of T-cell-receptor-enriched microvesicles at the immunological synapse. Nature (2014) 507(7490):118-23. doi:10.1038/ nature12951

Conflict of Interest Statement: The authors declare that the research was conducted in the absence of any commercial or financial relationships that could be construed as a potential conflict of interest.

Copyright (®) 2016 Rebmann, König, Nardi, Wagner, Manvailer and Horn. This is an open-access article distributed under the terms of the Creative Commons Attribution License (CC BY). The use, distribution or reproduction in other forums is permitted, provided the original author(s) or licensor are credited and that the original publication in this journal is cited, in accordance with accepted academic practice. No use, distribution or reproduction is permitted which does not comply with these terms. 